\title{
Treatment of Transposition of the Maxillary Canine Using Various Treatment Modalities
}

\author{
Hyosun Kim, Yoojun Kim, Kitaeg Jang, Youngjae Kim \\ Department of Pediatric Dentistry, School of Dentistry, Seoul National University
}

\section{Abstract}

Transposition is a unique and extreme form of ectopic eruption where a tooth develops and erupts in a position, normally occupied by an adjacent tooth.

Generally, three treatment options are available when the maxillary canine and first premolar are transposed. In the first treatment option, the transposed position of the teeth can be maintained such that the first premolar is moved to the position of the canine. Second, extraction of the maxillary first premolar can be considered. Third, the position of the transposed teeth can be corrected such that their normal positions in the arch are restored.

Factors that should be considered in treatment modality decision include function, occlusion, periodontal support, treatment time, patient cooperation, and esthetic demands. This report describes cases of maxillary canine-premolar transposition treated with each of the three aforementioned treatment options. In the first case, transposed teeth were arranged in their transposed position. The second case was an extraction case. In the third case, orthodontic treatment and surgical repositioning were conducted.

Key words : Tooth transposition, Maxillary canine, Orthodontic treatment

\section{I. 서 론}

전위는 한 영구치가 정상적으로는 다른 영구치가 있어야 할 위치에서 발달하고 맹출하는 상대적으로 드문 치아 위치 이상 중 하나이다. 가장 널리 받아들여지는 치아 전위의 병인은 다인 자 유전에 근거하는데, 그 이유는 가족력이 있는 경우가 흔하 고, 치아 무형성증, 왜소치, 치아 형태 변형 등의 문제가 전위된 치아를 가진 환자에서 높은 비율로 나타나기 때문이다 ${ }^{11}$. 이 외 에도 유치의 만기 잔존, 과잉치, 국소적 병적 진행상태 등 병인 에 대한 여러 가설이 제안된 바 있다2).

전위는 완전 전위와 불완전 전위로 구분 된다 ${ }^{3)}$. 완전 전위는 두 치아의 치관과 치근 전체가 바뀐 위치에서 평행하게 관찰된 다. 불완전 전위에서는, 치관은 그 위치가 바뀌어 있으나, 치근
단은 각각의 정상적인 위치에서 관찰된다. 혹은, 치관이 정상적 인 위치에 있고, 치근단이 전위된 경우도 이에 포함된다. 이 경 우, 두 이환된 치아의 치근은 겹쳐 보이고 서로 교차하여 지나 간다.

치아 전위는 편측에서 발생하는 경우가 양측성보다 많으며, 상악에 호발 한다. 상악의 경우, 견치와 제 1 소구치의 전위가 가 장 많으며, 측절치와 견치의 전위는 그보다 낮은 빈도로 발생한 다 ${ }^{4)}$. 흔하지 않게 중절치나 제 2 소구치, 혹은 제 1 대구치가 연관 되는 경우가 보고되고 있다 ${ }^{5-7)}$. 그러나 중절치와 측절치 간 전위 와 같은 견치가 연관되지 않은 증례는 매우 드물다. 가장 많이 보고되는 상악 견치와 제 1 소구치 전위의 특징은 다음과 같다. 잔존된 유견치가 있는 경우가 많고, 영구 견치는 제 1 소구치와 제 2 소구치 사이에 위치하며 흔히 협측에 위치하고 종종 근심

Corresponding author : Youngjae Kim

Department of Pediatric Dentistry, School of Dentistry, Seoul National University, 101 Daehak-ro, Jongno-gu, Seoul, 110-744, Korea

Tel: +82-2-2072-3080 / Fax: +82-2-744-3599 / E-mail: neokarma@snu.ac.kr

Received November 14, 2013 / Revised November 21, 2013 / Accepted November 27, 2013 
순측 회전되어 있다. 전위된 제 1 소구치는 거의 항상 근심 설측 으로 90 도까지 회전되어 있으며 종종 구개측에 위치한다. 전위 된 부위에 일시적인 총생이 존재하며, 특히 유전치가 잔존되어 있을 때 그러하다 ${ }^{4}$.

치아 전위의 치료는 치근첨의 위치, 심미성, 환자의 나이, 환 자의 치료 동기 및 기대 수준 정도를 평가하여 결정한다. 또한, 치료 도중 일어날 수 있는 치아와 주위 조직의 손상 가능성과 치료 기간 또한 고려되어야 하고, 치료에 앞서 환자와 이에 대 한 상의가 필요하다. 치료 방법은 전위된 치아 중 하나를 발치 하는 것, 치아를 전위된 위치에 배열하는 것, 그리고 전위를 완 전히 수정하여 배열하는 방법으로 나뉜다. 마지막 방법은 외과 적 방법을 동반하거나 동반하지 않을 수 있다. 본 증례들은 견 치와 제 1 소구치의 전위로 서울대학교 치과병원 소아치과에 내 원한 환자들로서, 각각 전술한 치료 방법 중 하나를 사용하여 양호한 결과를 얻었기에 이에 보고하는 바이다.

\section{II. 증례 보고}

\section{1. 증례 1}

11 세 5 개월 된 여아가 상악 양측 견치의 위치 이상으로 본원 내원하였다. 파노라마 방사선 검사 결과, 상악 양측 견치와 제 1 소구치의 전위 및 하악 양측 제 2 소구치의 맹출 방향 이상이 관 찰되었다. 3 차원 전산화 단층촬영 결과, 양측 제 1 소구치의 치 근첨이 견치 치근의 근심 구개측에 위치하고, 치관 또한 제 1 소 구치가 견치의 근심에 위치하는 완전 전위임을 알 수 있었다

(Fig. 1). 이와 관련하여 가족력이나 외상의 병력은 없었다.

교정 검사 결과, 골격성 3 급 부정교합 및 치성 1 급 부정교합 으로 진단되었다. 상악은 양측 유견치, 제 1 유구치, 좌측 제 2 유 구치 발치 후 Nance 구개 호선을 장착, 하악은 양측 제 1 유구 치, 제 2 유구치 발치 후 설측 호선을 장착하였다. 9 개월 후, 상 악 좌측 견치를 제외한 모든 영구치가 출은하였으며 (Fig. $2 \mathrm{a}$ ),
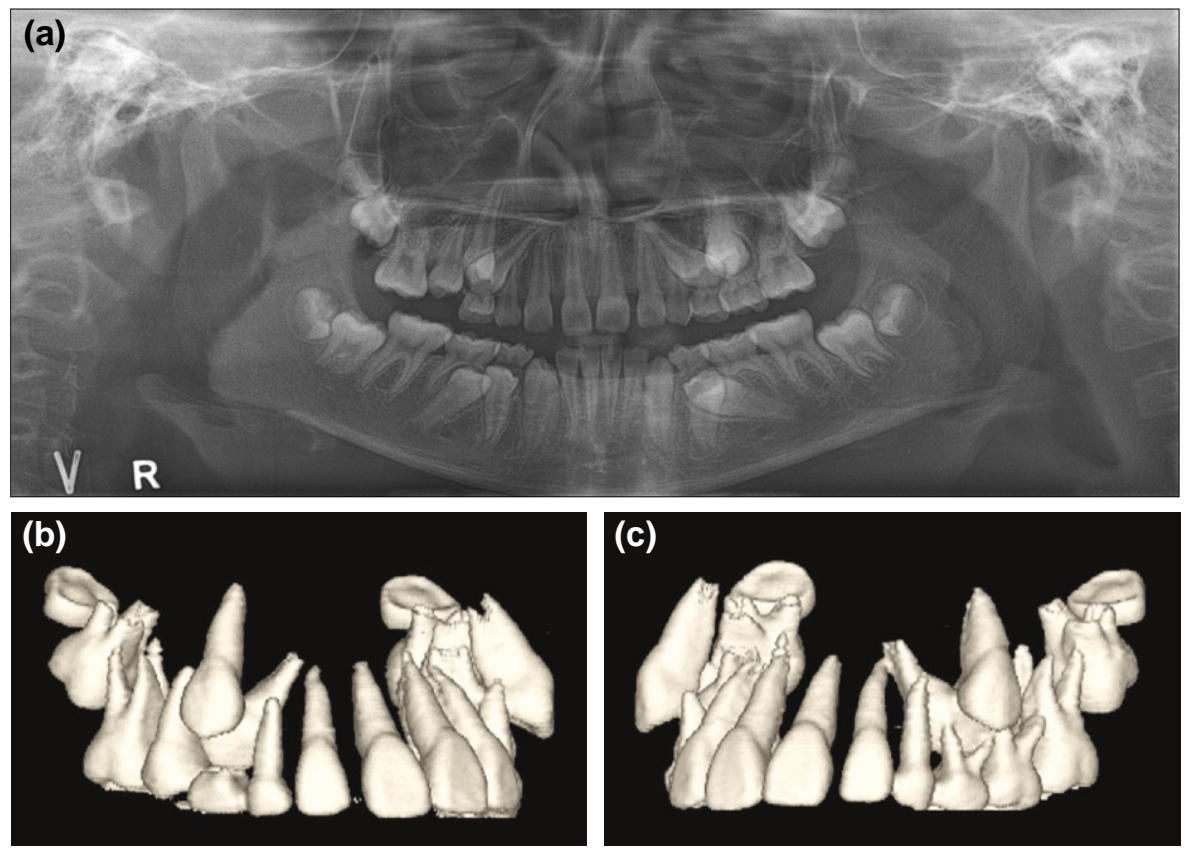

Fig. 1. Panoramic and 3D dental CT view. (a) Complete transposition of the bilateral maxillary canines and first premolars. (b), (c) The crowns of the first premolars were rotated mesiopalatally and their root apices were located mesially to the canines, respectively.
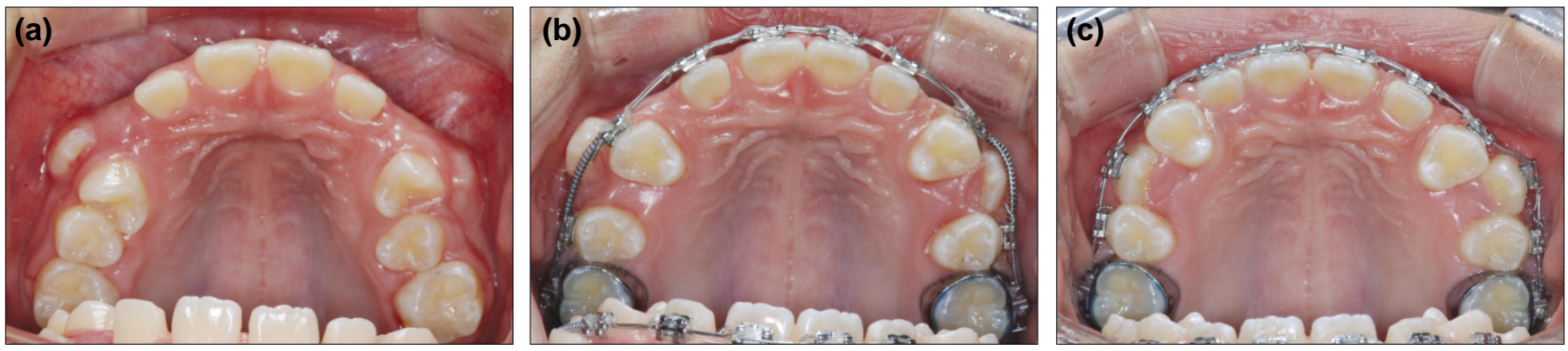

Fig. 2. Intraoral clinical photographs. (a) Before orthodontic treatment. (b) After 2 months. The first premolars were moved mesially using an open coil spring while creating space for the canines. (c) After 5 months. The leveling process of both canines was evident. 

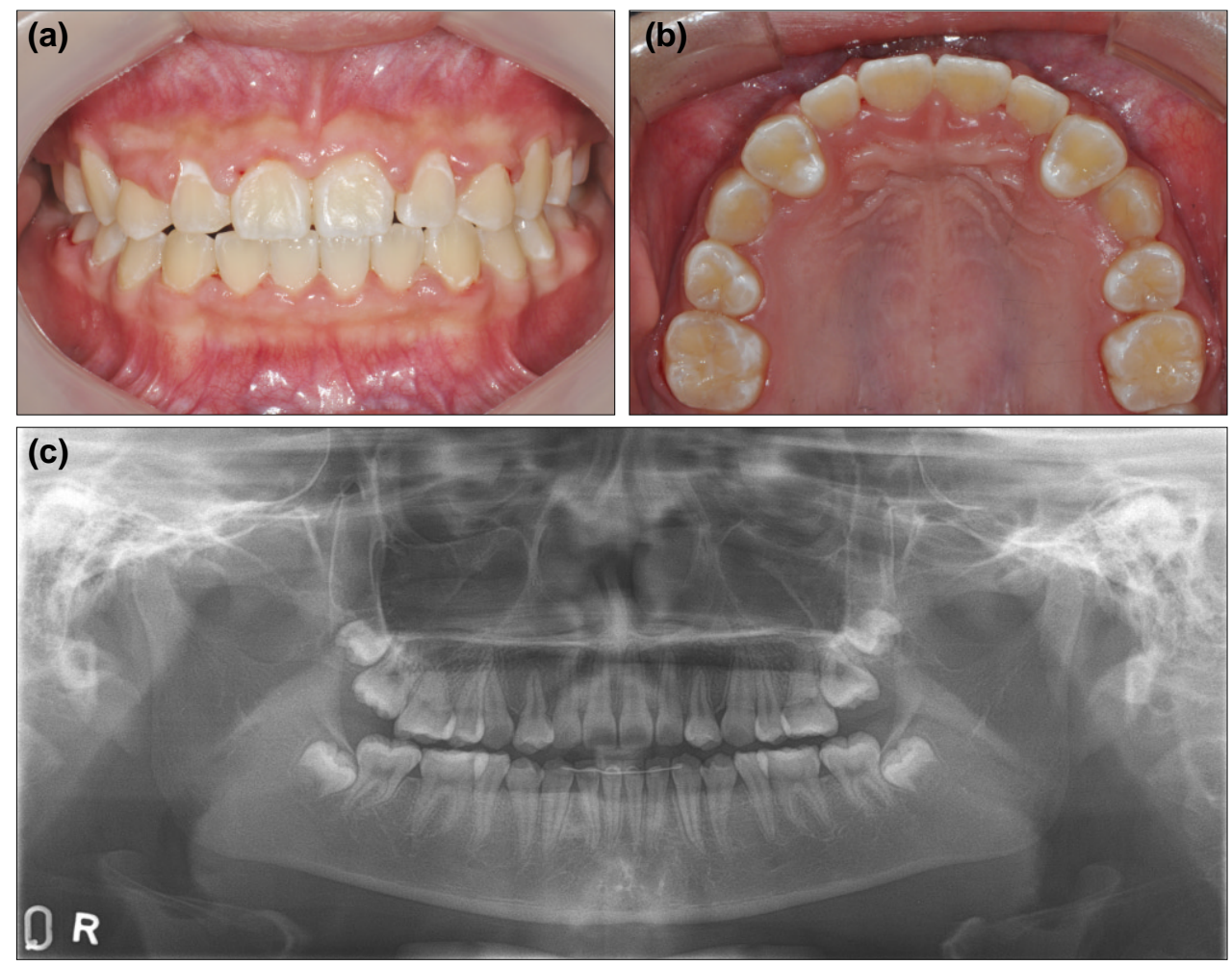

Fig. 3. Frontal and occlusal photographs after 18 months of treatment. (a) Frontal view of the intraoral photograph. The midline is slightly deviated and the gingival line is esthetically compromised. In order to improve aesthetics, additional periodontal surgery was necessary. (b) Occlusal view of the intraoral photograph. The canines and first premolars were aligned in transposed positions. (c) Panoramic radiograph. The canines and first premolars were aligned without root resorption.

이에 상, 하악 치아에 고정성 교정 장치를 부착하였다. 상악 양 측 제 1 소구치를 open coil을 사용하여 근심으로 이동시켜 견치 가 맹출할 수 있는 공간을 마련하고(Fig. $2 \mathrm{~b}$ ), 교정 장치 부착 3 개월 경과 후에 상악 좌우측 견치에 브라켓을 부착하여 함께 레벨링을 시행하였다(Fig. 2c). 양측 하악 제 2 소구치는 별다른 견인 없이 자발적으로 맹출하였으며, 고정성 교정 장치를 통해 회전 조절을 시행하였다. 19 개월간의 교정 치료 끝에 상악 양 측 견치와 제 1 소구치는 전위된 위치로 배열되었으며, 치근 흡 수는 일어나지 않았다(Fig. 3).

\section{2. 증례 2}

10세 9개월 된 여자 환아로 앞니가 고르지 않음을 주소로 내 원하였다. 내원 당시 상악 좌, 우측 유견치의 잔존이 관찰되었 고, 방사선 검사에서 양측 제 1 소구치의 치근이 견치의 치근보 다 근심에 위치함을 알 수 있었다. 골격성 I급 부정교합이며 절 단 교합, 상악 $5.9 \mathrm{~mm}$ 공간 부족, 하악 $5.9 \mathrm{~mm}$ 공간 부족 및 중등도의 양측성 구순 돌출을 보였다(Fig. 4). 또한, 하악의 3 전치가 관찰되었다. 아직 혼합치열기이며 유견치의 발거 및 변
형된 Nance 구개 호선 등을 이용한 견치의 근심 견인으로 이루 어질 수 있는 차단 교정이 어려울 것으로 생각되어, 영구치열기 에 재평가하기로 하고 주기적으로 관찰하였다.

26 개월 후, 영구치 맹출이 완료되었다. 전위된 견치가 제 1 소 구치와 제 2 소구치 사이의 협측에 존재하였고 방사선 검사 상 완전 전위로 진단되었다(Fig. 5). 상, 하악 모두 $5.9 \mathrm{~mm}$ 의 중 등도의 공간 부족량을 보임과 상, 하순의 돌출, 환아가 개방교 합 경향을 보임을 고려하여 상, 하악 제 1 소구치를 발거하였다. 상악 제 1 대구치를 횡 구개 호선으로 고정원을 보강한 뒤 상, 하 악 치아에 고정성 교정 장치를 부착하여 교정 치료 하였다. 24 개월 후, 하악 3 전치를 유지한 상태로 치아의 배열을 마무리하 였다(Fig. 6). 환아는 성장기 환자로서 치료 후 측모 두부 방사 선 검사 분석 결과, 많은 수직적인 성장과 하악의 후하방 회전 이 일어났고 하악 평면각이 증가하였다. 구순 돌출도가 개선되 었고 상악 전치의 각도가 개선되었으나, 하악 전치의 공간을 치 료 후반기에 폐쇄한 것의 영향으로 하악 전치는 설측 경사 되었 다(Table 1, Fig. 7). 교정치료 종료 후 2년 3개월 후까지 상악 에 가철성 보정 장치와 하악에 설측 부착 고정성 유지 장치를 사용하여 보정하였다. 

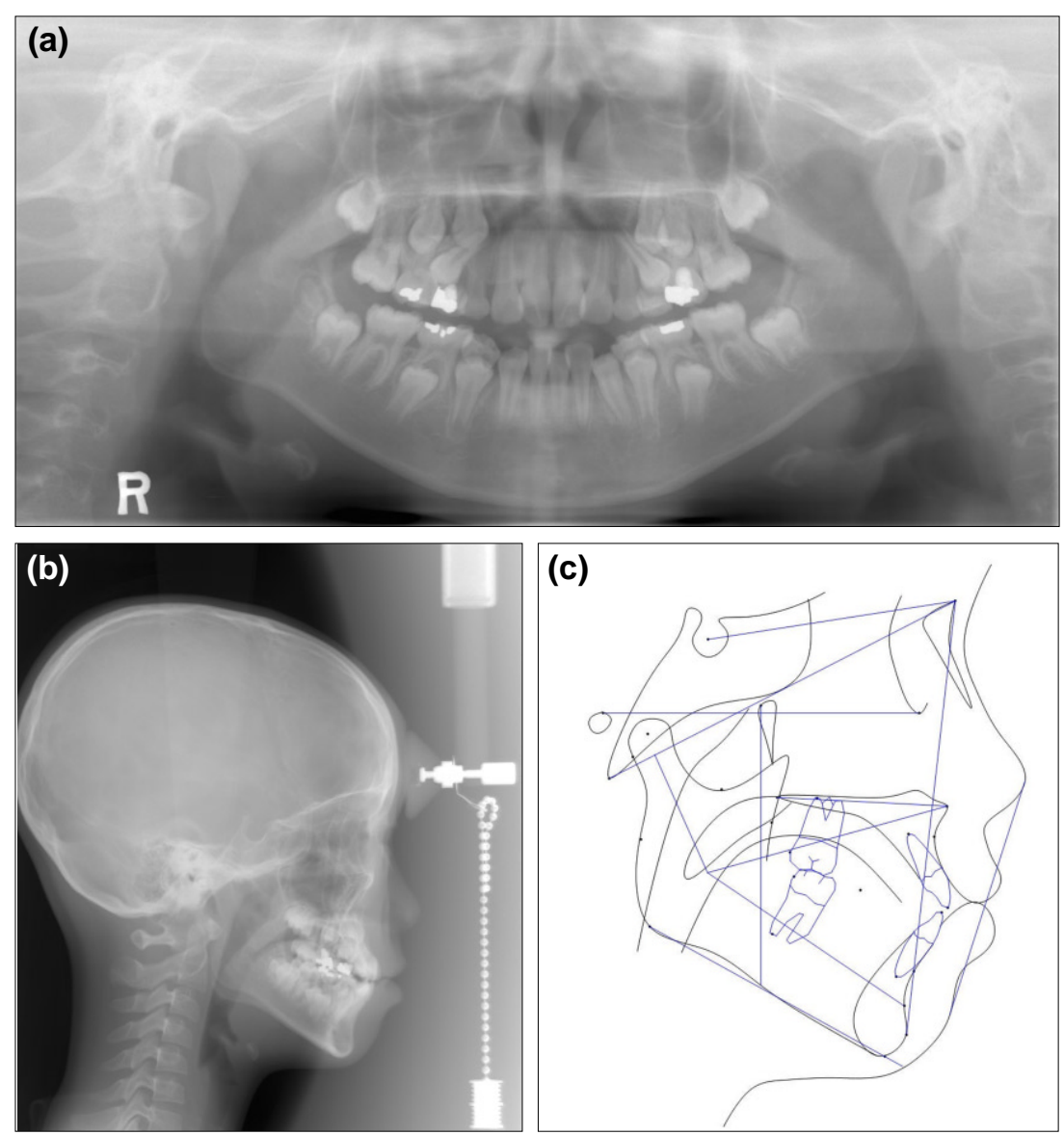

Fig. 4. Initial radiographs. (a) Panoramic radiograph. The root apices of the first premolars on both sides were located mesially to the canines. The mandibular right lateral incisor was missing congenitally. (b) Lateral cephalogram. (c) Cephalometric tracing. Moderate lip protrusion and upper incisor labioversion were observed.
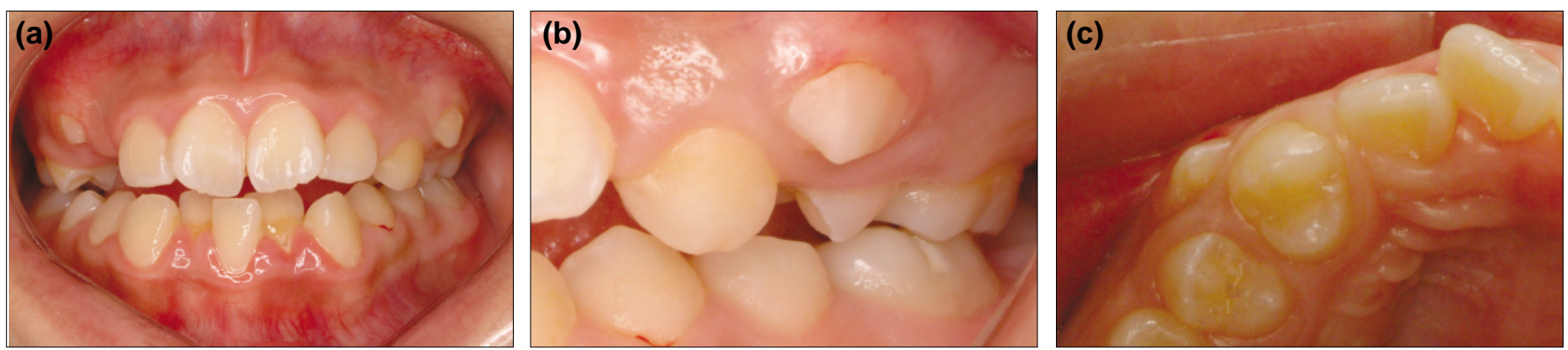

(d)

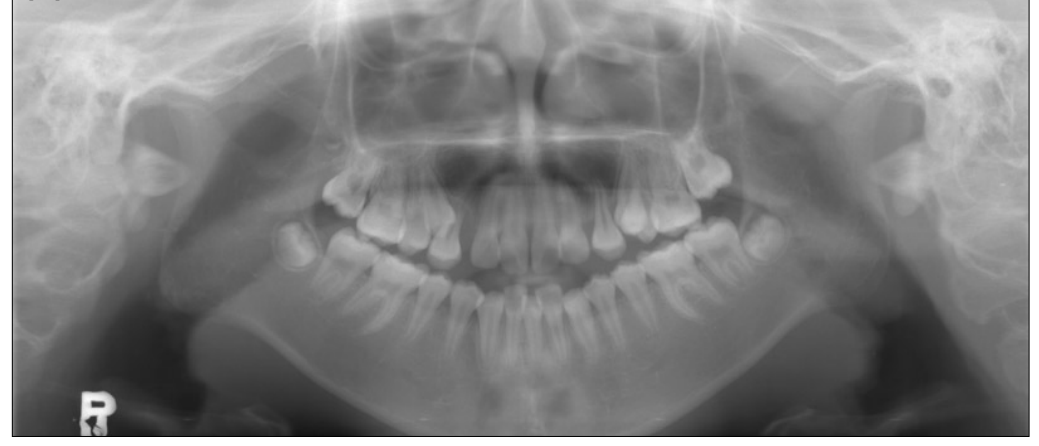

Fig. 5. Initial records. (a) Frontal view of the intraoral photograph. The overbite was shallow. Generalized crowding and the mandibular 3 incisor were observed. (b) Left view of the intraoral photograph. The canine was located buccally between the first and second premolars. (c) Right occlusal view of the intraoral photograph. The first premolar was rotated mesiopalatally. (d) Panoramic view before orthodontic treatment. Eruption of permanent teeth has been completed. Additionally, complete transposition of the canine and first premolar was observed. 

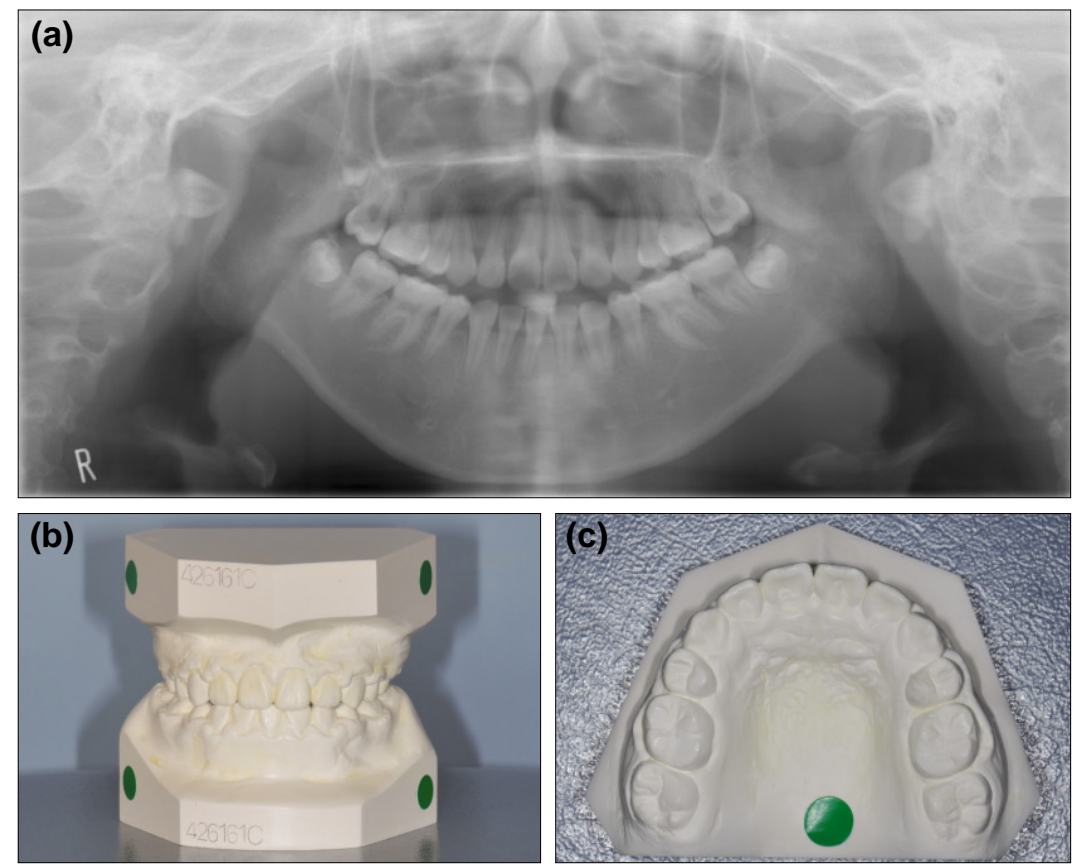

Fig. 6. Final records. (a) Panoramic view. The 4 first premolars were extracted and crowding was eliminated. (b) Frontal view of the model. A midline discrepancy due to the mandibular 3 incisors was observed. (c) Occlusal view of the model. The canine was aligned with extraction of the first premolar.
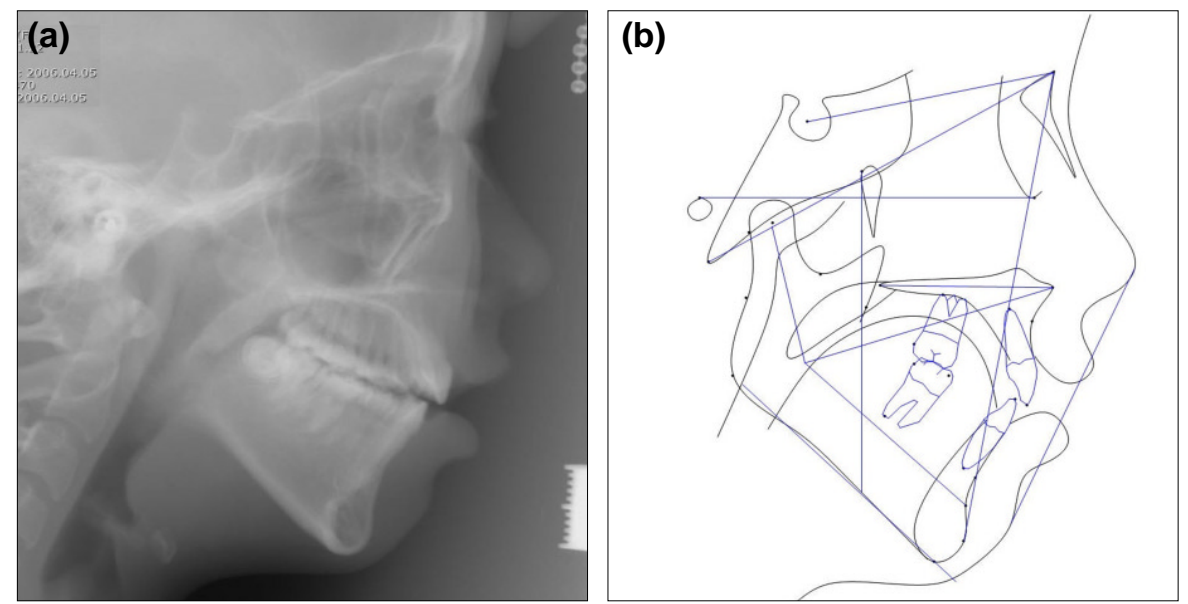

Fig. 7. Post-treatment cephalogram. (a) Lateral cephalogram. Vertical growth and an open bite tendency was observed. (b) Cephalometric tracing. Lip protrusion was decreased. The maxillary and mandibular incisors were inclined lingually.

Table 1. Summary of cephalometric analysis

\begin{tabular}{cccc}
\hline Measurement & Norm & Pretreatment & Posttreatment $^{\dagger}$ \\
\hline SNA & $81.0 \pm 2.7$ & 75.9 & 75.1 \\
SNB & $78.5 \pm 2.7$ & 74.7 & 68.8 \\
ANB & $2.5 \pm 2.0$ & 1.2 & 6.3 \\
U1 to FHP ( $\left.{ }^{\circ}\right)$ & 111 & 120.0 & 106.2 \\
L1 to MP ( ${ }^{\circ}$ & $96.0 \pm 6.0$ & 96.0 & 83.8 \\
FMIA $\left.^{\circ}\right)$ & $67.0 \pm 2.0$ & 55.0 & 53.4 \\
FMA ( $\left.{ }^{\circ}\right)$ & $25.0 \pm 2.0$ & 28.9 & 42.7 \\
UL to E. plane (mm) & $-0.5 \pm 2.0$ & 2.0 & 1.4 \\
LL to E. plane (mm) & $3.0 \pm 1.7$ & 4.8 & 4.0 \\
\hline
\end{tabular}

Pretreatment records at age 10 years 9 months.

${ }^{\dagger}$ Posttreatment records at age 15 years 3 months. 


\section{3. 증례 3}

11 세 3 개월의 남아가 좌측 상악 견치의 매복을 주소로 본원 내원하였다. 구강 내 소견과 더불어 파노라마 및 3 차원 전산화 단층촬영 방사선 검사 결과, 상악 좌측 견치와 제 1 소구치의 완 전 전위로 진단되었다(Fig. 8, 9). 교정 검사 결과, 골격성 및 치성 1 급 부정교합으로 진단되었으며, 공간 분석 결과, 상악 $0.8 \mathrm{~mm}$, 하악 $2.6 \mathrm{~mm}$ 의 공간 부족을 보였다. 상악 우측 중절 치는 환아가 9 세 경, 외상으로 치관 파절되어 근관 치료 및 복 합레진 수복한 병력이 있었다.

외과적 노출과 교정적 견인만으로는 견치와 제 1 소구치의 위 치를 바로잡는 것이 어려울 것으로 생각되어, 외과적 재위치 후 교정 치료하기로 하였다. 국소마취 하에 좌측 유견치를 발거한 후, 상악 좌측 견치의 치관이 제 1 소구치의 근심에 오도록 치관 을 재위치 시키고 치근의 이동은 최소화하였다. 견치가 구강 내 노출되도록 봉합 후, 레진 강선 고정을 시행하였다(Fig. 10). 좌측 유견치는 발거하였다. 수술 7 주 후, 상악에만 고정성 교정 장치를 부착하여 치료하였다. 특히 견치 치근의 이동에 많은 시 간이 소요되었다. 9 개월경과 후, 상악 좌측 견치와 소구치가 제
위치에 배열되었고 상악 좌측 견치의 치수 괴사는 관찰되지 않 았으나, 상악 좌측 제 1 소구치 치근의 경미한 근심 만곡이 관 찰되었다(Fig. 11).

\section{III. 총괄 및 고찰}

상악 견치는 제 1 소구치와 측절치의 구개측 상방 및 안와 하 방에서 발달하기 시작한다. 긴 맹출 기간에 상악 견치는 근심 순측으로 이동하고 순측 전정 높은 곳에서 촉진된다. 상악 견치 가 이 기간에 정상적인 맹출 경로에서 벗어나면, 매복되거나 다 른 치아의 위치로 이동하여 이소 맹출되기도 한다 ${ }^{8}$. 이렇게 긴 맹출 경로는 상악 견치의 잦은 매복이나 위치 이상의 주원인 중 하나로 알려져 있다 ${ }^{9}$. 상악 견치의 전위는 치배가 비정상적인 위치에서 발생하거나 정상 맹출 경로로부터 이탈하는 것이 그 원인이 된다 ${ }^{10)}$ 상악 견치와 측절치의 전위는 주로 유치열 시기 의 안면 외상에 의하여 발생하는 경우가 많은 반면 ${ }^{11}$, 이른 시기 의 외상이나 치아의 조기 상실이 상악 견치와 제 1 소구치의 전 위에 기여한다는 증거는 없다 ${ }^{12)}$.

상악 견치와 제 1 소구치의 전위는 치아 전위의 가장 흔한 종 류이다. 이를 치료하는 방법은 다양한데 치아 발거를 동반하거
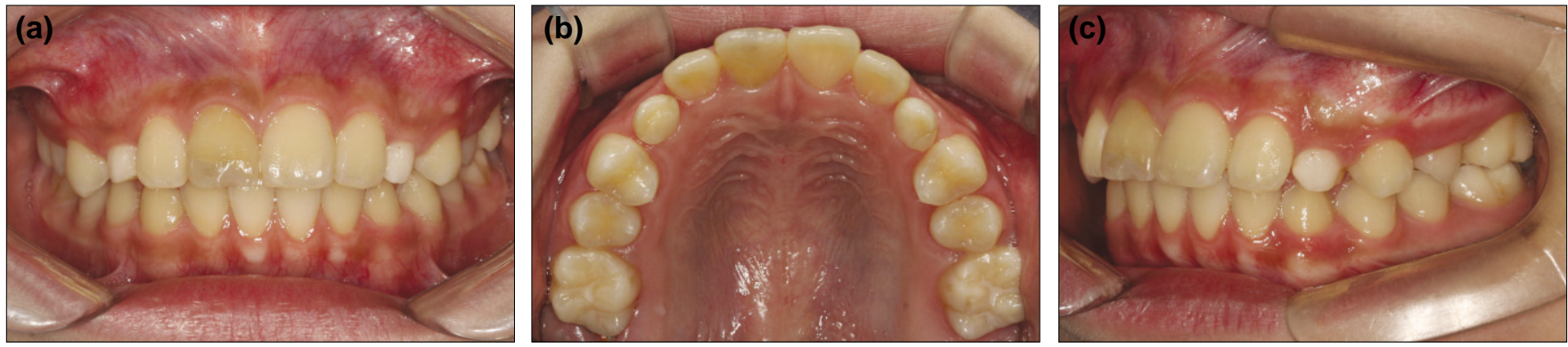

Fig. 8. Initial intraoral photographs. (a) Frontal view. The maxillary right central incisor was discolored due to a history of trauma. (b) Occlusal view. Primary canines on both sides are remained. With the exception of the canines, all permanent teeth in the arch were erupted. (c) Left view. The left first premolar was rotated mesiopalatally.
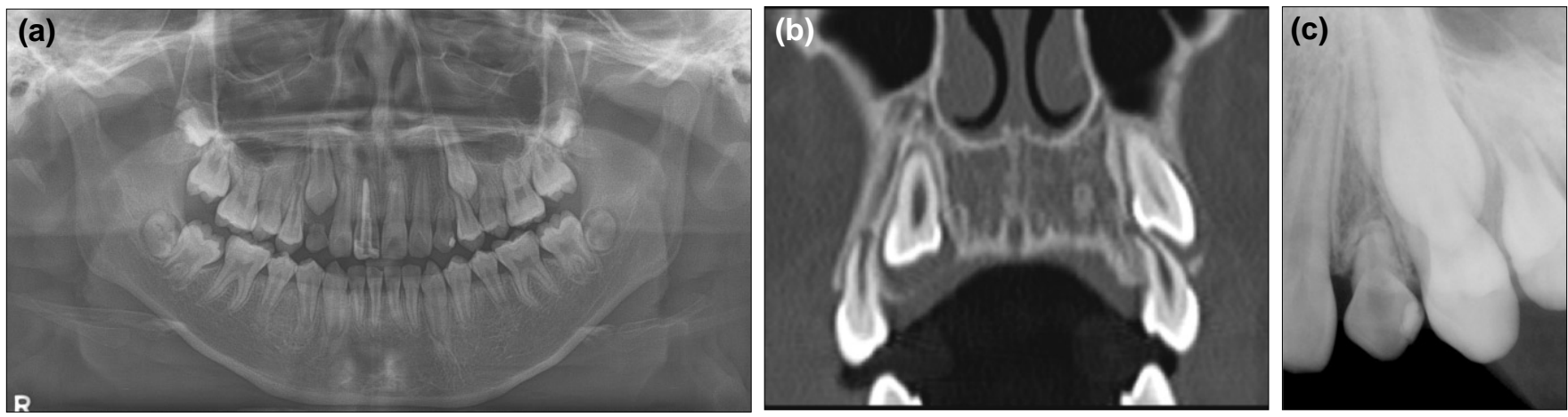

Fig. 9. Initial radiograph. (a) Panoramic radiograph. The maxillary left canine was erupting between the first and second premolars. The maxillary right canine was erupting ordinarily. (b) Reformatted localization CT. The maxillary left canine is located buccally to the first premolar. (c) Intraoral radiograph. The canine and first premolar appeared to overlap. 

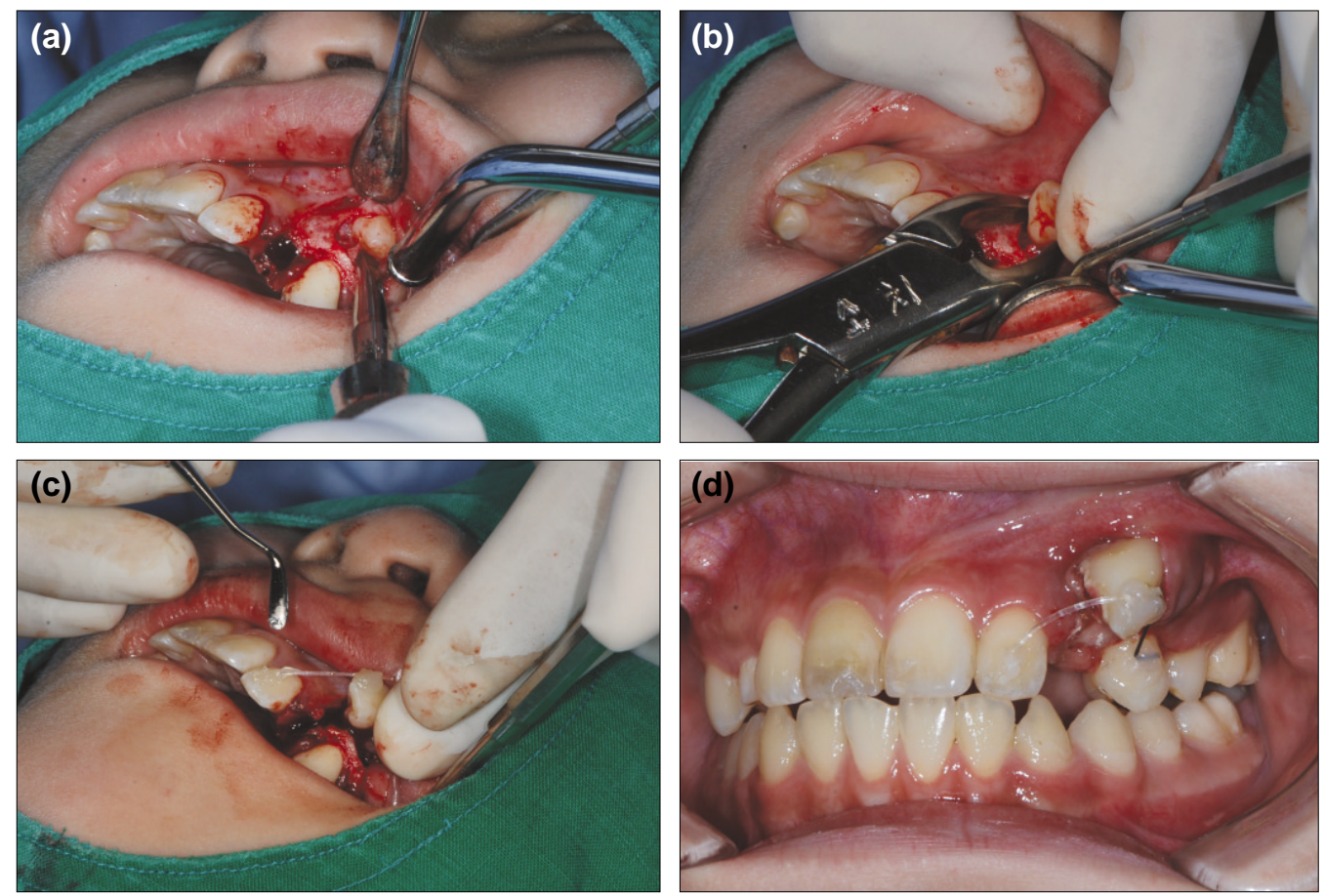

Fig. 10. Surgical repositioning of the canine. (a) The maxillary canine was luxated using an elevator. (b) The crown of the canine was repositioned to the mesial side of the first premolar. (c) Resin-wire splinting was made. (d) 1 week after surgery. Uneventful healing was observed.
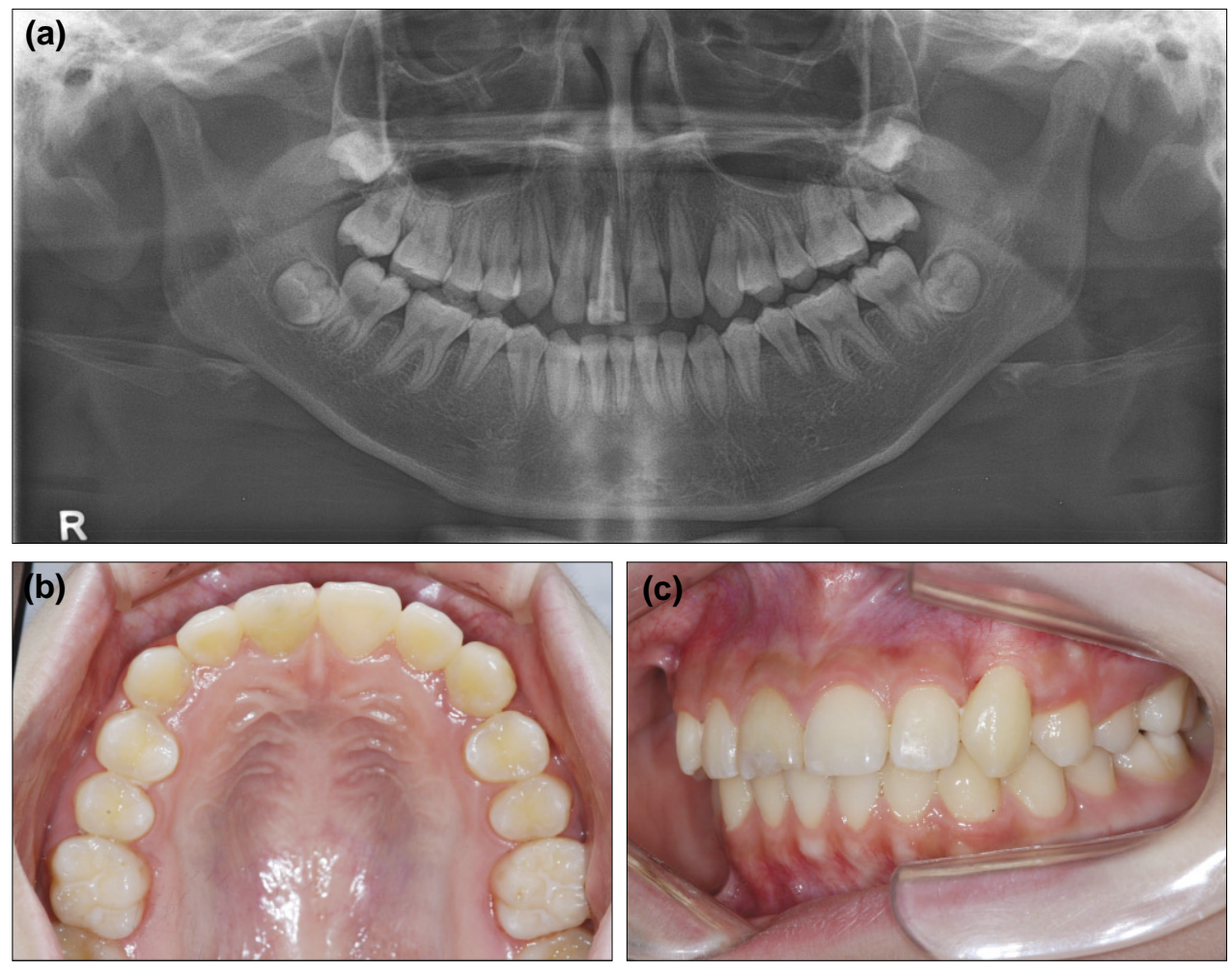

Fig. 11. Final records. (a) Panoramic radiograph. The root apex of the maxillary left first premolar is dilacerated due to the canine. The maxillary left canine showed pulp obliteration. (b, c) Intraoral photograph. The maxillary left canine and premolar were aligned in correct positions. 
나 동반하지 않을 수 있다. 발치를 동반한 치료 시에는 심한 치 아우식증에 이환되어 있거나 수복 불가능한 치아를 우선하여 발치한다. 만일 이러한 치아가 없다면, 일반적으로 제 1 소구치 를 발치하게 된다. 이는 총생을 해소하고 전위된 견치의 위치를 쉽게 바로 잡을 수 있다는 장점이 있다. 또한, 더욱 간단한 역학 을 사용하여 짧은 시간 안에 치료를 끝낼 수 있다. 그러나 전치 각도나 환자의 안모 악화 가능성이 있는 경우 발치 치료는 제한 된다. 비발치 치료에서 치아를 전위된 위치에 배열하는 방법은 전위를 수정하여 배열하는 방법보다 대체적으로 더 짧은 치료 기간을 요구한다. 단점으로 견치와 소구치의 토크 조절이 어렵 고 하악 운동 시에 교합 간섭이 있을 수 있다. 또한, 전위를 수 정하는 방법보다 심미적으로 불리하다. 전위를 바로 잡아 치아 를 제 위치에 배열하는 방법은 치료 기간이 더 길고, 환자의 협 조가 더 많이 필요할 수 있다. 그리고 치주 조직에 손상을 주지 않고 치근 간섭 없이 전위를 수정하는 것이 어려울 수 있다. 그 러나 이 방법은, 완전한 교두 감합으로 기능적인 교합을 달성할 수 있고 심미적으로도 이상적이다. 외과적 재위치술 또는 자가 치아 이식을 이용하여 견치를 제 1 소구치 근심으로 옮긴 후, 교 정 치료로 마무리하는 방법은 교정 역학만을 이용하여 전위를 바로 잡는 방법보다 더 비용-효율 측면에서 우수하고 인접치의 손상이 없다는 장점이 있다. 그러나 예후를 예측하기 힘들고 치 수 괴사, 치근 흡수, 유착의 발생 가능성이 있으며, 이에 따른 치아의 상실 위험성이 있다. 따라서 치료 방법 선택 시에는 장, 단점을 고려하여 최선의 선택지를 결정하여야 한다.

본 3 증례는 모두 완전 전위가 일어났으며, 견치의 교두정이 제 1 소구치의 치근 하방에 위치하여 차단 교정을 시행하기에는 전위의 발견이 늦었다. 증례 1 에서는 초진 시, 견치와 제 1 소구 치의 치근 각도가 매우 큰 각으로 발산되는 위치에 있음이 발견 되었다. 따라서 치근의 각도를 조절하면서 치아를 원래의 자리 로 배열하기에는 무리가 있어 전위된 위치로 배열하였다. 이렇 게 전위된 위치로 견치와 제 1 소구치를 배열할 경우, 치아의 토 크로 인해 심미성이 저해되고, 하악 운동 중에 교두 간섭으로 불편감을 일으킬 수 있다는 문제가 있다. 그러나 상대적으로 짧 은 기간 안에 치근 흡수나 치주 조직의 손상 우려 없이 치료를 종료할 수 있다는 장점이 있다. 증례 1 에서, 견치 및 소구치의 토크 조절과 정중선 일치 등이 마무리 단계에서 시행되어야 했 으나, 환자의 협조도 부족과 브라켓 주변 탈회 현상, 치은 비대 의 문제로 환아와 보호자 모두 빠른 치료 종료를 원하였다. 환 아는 제 1 소구치로 인한 이물감이나 불편감을 호소하지도 않았 고, 추가적인 치료를 원하지도 않았다. 마무리 단계에서 교합 조정을 시행하였다.

치아 전위 시에 악궁 장경과 치아 크기의 부조화가 크고 상, 하순 돌출이 있어 발치 교정이 필요한 경우, 전위된 치아를 발 거하는 방법도 고려 대상이 될 수 있다. 증례 2 의 경우, 상, 하 악 모두 중등도의 공간 부족을 보였고, 상악 전치의 순측 경사, 상, 하순의 돌출, 골격성 개방교합 경향을 보임을 고려하였을 때, 발치 교정 치료가 적절하였다. 이때, 견치를 발거하는 것 보 다는 제 1 소구치를 발거하고 견치를 제자리로 배열하는 것이 심
미적, 기능적으로 유리하다. 하악의 경우, 좌측 측절치의 선천 적 결손이 있으므로 좌, 우측 소구치 대신 우측 측절치 하나를 발치하는 것도 고려하였으나 구순 돌출도 개선 및 최적의 심미 성, 교합의 안정성을 위해 교정 치료 후 성인기에 하악 전치 임 플란트 및 보철을 하는 것으로 계획하였다. 더하여, 환아의 개 방교합 성장 경향을 치아 이동으로 보상하기 위한 목적으로, 제 1 소구치 발치를 최종 결정하였다. 그러나 치료 중간에 보철적 처치가 추가로 필요치 않도록 치료를 끝내달라는 보호자의 요 청이 있었다. 수평 피개도 증가와 정중선의 불일치, 안정성에 영향을 미칠 수 있음을 설명하였으나 치료 후반기에 하악 전치 의 결손 공간을 폐쇄하게 되었다. 치료 중 전치부 개방교합은 상악 호선에 역스피만곡, 하악 호선에 스피만곡을 부여하고 견 치 부위의 수직적 고무줄을 이용하여 치아치조 보상을 유도하 여 폐쇄하였다. 교정 치료 결과, 상악 견치의 토크 및 배열은 심 미적으로 우수하였다. 그러나 치료 중간에 치료 계획을 수정한 것의 영향으로 하악 전치의 설측 경사가 일어났고, 초진과 비교 하여 5년 동안 많은 수직적 성장이 일어나 골격성 개방교합의 경향을 보였다.

전위된 치아를 제자리에 위치시키는 방법으로 여러 증례가 보고된 바 있다. Filho 등히는 분절 호선으로 견치의 근심측 이 동, 제 1 소구치의 구개측 이동을 개별적으로 조절하여 전위를 교정하였으며, Oztoprak 등ㄴ)은 교정용 미니 임플란트를 식립 하여 제 1 소구치를 구개측 이동시킨 후, 견치의 근심 이동 및 제 1 소구치의 원심 이동으로 전위를 교정하였다. 적절한 증례에서 전위된 치아를 제 위치에 배열하는 것은, 심미적으로나 기능적 으로 가장 좋은 결과를 낼 수 있으나, 치료 기간의 연장은 피할 수 없다. 본 증례 3 에서는 수술적인 방법을 이용하여 견치를 재 위치 시켰다. 이 방법은 교정만으로 치아를 배열하는 것보다 훨 씬 짧은 치료 기간을 필요로 한다. 또한, 자가 치아 이식술보다 는 치아에 외상을 덜 주면서 교정적 견인으로 원래의 위치에 배 열할 수 있다. 본 증례에서는 견치의 자가 치아 이식술도 고려 하였으나 이를 위해서는 유견치 발치 공간이 견치를 이식하기 에 충분치 않으므로 추가적인 골 삭제가 필요하였다. 따라서 이 경우, 견치의 구강 외 노출 시간 증가와 유견치 발치와의 치주 인대 상실이 예상되고 재부착(reattachment)보다는 신부착 (new attachment)에 의한 치주인대 치유를 기대해야 한다. 그러나 이러한 과정 없이도 견치 치관을 충분히 근심으로 이동 시켜 고정할 수 있었으므로 외과적 재위치술만을 시행하였다. 그러나 뒤이은 교정 치료에서 견치 치근의 각도 조절이 쉽지 않 았다. 자가 치아 이식술을 시행했다면 치근 위치 조절이 더욱 용이했을 것으로 생각된다. 본 증례에서는 견치의 치수 괴사가 일어나지 않았고 결과적으로 근관 치료가 필요치 않았으며 9개 월이라는 상대적으로 짧은 기간 내에 교정 치료가 완료되었다. 그러나 견치의 토크 조절 불충분 및 부착 치은 감소 등 심미적 인 문제가 있었다. 또한, 상악 좌측 제 1 소구치의 치근은 근심으 로 만곡되었으며 이는 치료 전, 견치가 제 1 소구치의 원심 협측 에 위치하여 있던 것의 영향을 받은 것으로 생각된다.

세 증례 모두 가족력이나 외상의 병력은 없었으나, 치아의 선 
천성 결손 및 유치의 만기 잔존, 다른 치아의 맹출 방향 이상 등 이 함께 나타났다. 이는 상악 견치와 제 1 소구치의 전위가 다인 자 유전 모델에 근거한 유전적 영향의 결과로 나타나며, 부분적 무치증, 왜소 측절치 등 부가적인 치과적 이상이 높은 빈도로 존재함이 이를 뒷받침할 수 있다는 Peck 등의 연구 결과와 일 치한다 ${ }^{15)}$.

$$
\text { IV. 요 약 }
$$

치아 전위는 치열궁 내의 두 인접치의 위치가 바뀐 것으로 이 에 대한 교정적 치료를 할 때에는 심미, 기능, 인접치의 치주 조 직 손상 가능성, 치료 기간 등을 고려하여 전위된 치아를 제자 리에 배열할 것인지, 바뀐 위치에 배열할 것인지를 결정해야 한 다. 본 증례들에서는 치아를 변위된 상태로 배열하는 방법, 전 위된 두 치아 중 한 치아를 발거하고 교정하는 방법, 외과적 재 위치와 교정 치료를 통한 배열 방법을 통하여 각각 양호한 결과 를 얻었다.

\section{References}

1. Peck L, Peck S, Attia Y : Maxillary canine-first premolar transposition, associated dental anomalies and genetic basis. Angle orthod, 63:99-109, 1993.

2. Farret MM, Farret MM, Hollweg H, et al. : Unusual orthodontic approach to a maxillary canine-premolar transposition and a missing lateral incisor with longterm follow-up. Am J Orthod Dentofacial Orthop, Nov:142:690-7, 2012.

3. Shapira Y, Kuftinec MM : Tooth transpositions: a review of the literature and treatment considerations. Angle Orthod, 59:271-276, 1989.

4. Shapira Y, Kuftinec MM : Maxillary tooth transpositions: characteristic features and accompanying den- tal anomalies. Am J Orthod Dentofacial Orthop, Feb;119:127-34, 2001.

5. Jackson M : Upper canine in position of upper central incisor. Br. Dent J, 90:243, 1951.

6. Joshi MR, Gaitonde SS : Canine transposition of extensive degree: a case report. Br Dent J, 121:2212, 1966.

7. Hallet GE : A maxillary canine erupting in the first molar region. Br Dent J, 72:191-2, 1942.

8. Dewel BF : The upper cuspid: its development and impaction. Angle Orthod, 19:79-90, 1949.

9. Ooё T: Human tooth and dental arch development. Tokyo: Ishiyaku Publishers, 1981.

10. Mader C. Konzelman JL : Transposition of teeth. JADA, 98:412-413, 1979.

11. Van Gool AV : Injury to the permanent tooth germ after trauma to the deciduous predecessor. Oral Surg Oral Med Oral Pathol, 35:2-12, 1973.

12. Singh GP, Sharma VP, Singh GK, et al. : Maxillary canine-First premolar Transposition - Orthodontic Management - A Case Report. J Ind Orthod Soc, 39:14-19, 2006.

13. Filho LC, Cardoso MA. An TL, Bertoz FA : Maxillary canine-first premolar transposition. Angle Orthod, 77:167-175, 2007.

14. Oztoprak MO, Demircan C, Arun T : Correction of a maxillary canine-first premolar transposition using mini-implant anchorage. Korean Journal of Orthodontics, 41:371-378, 2011.

15. Peck L, Peck S, Attia Y : Maxillary canine-first premolar transposition, associated dental anomalies and genetic basis. Angle Orthod, 63:99-10, 1993. 
국문초록

\title{
다양한 치료법을 사용한 상악 견치 전위의 치료
}

\author{
김효선 · 김유준 · 장기택 · 김영재
}

서울대학교 치의학전문대학원 소아치과학교실

치아 전위는 치아 이소 맹출의 극단적인 형태로, 인접한 두 치아의 위치가 서로 바뀐 상태로 발육하고 맹출하는 치아 위치 이상이다. 상악 견치와 제 1 소구치의 전위가 가장 흔하게 발견되는데, 이는 다음의 세 가지 방법으로 치료할 수 있다. 첫 번째 방법은 치아를 전위된 상태로 배열하는 것이며, 두 번째 방법은 전위된 두 치아 중 한 치아를 발치하고 교정 치료하는 것이 다. 세 번째는, 전위된 치아를 원래의 위치로 되돌려 배열하는 방법이다.

치료 방법을 결정할 때에는 기능, 심미, 지지 치주 조직의 손상 가능성, 치료 기간, 환자의 협조도, 환자의 심미적 요구도를 고려하여야 한다. 본 증례는 견치와 제 1 소구치 간의 전위가 일어난 환자 세 명의 교정 치료에 관한 것으로, 각기 다른 치료 방법을 사용하여 양호한 결과를 얻었기에 이에 보고하는 바이다.

주요어: 전위, 상악 견치, 교정 치료 